\section{Revista de la \\ Universidad del Thulia}

Fundada en 1947 por el Dr. Jesúns Enrique Lossada

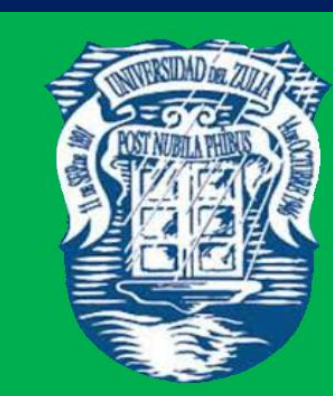

Ciencias del

Algreo

Ingemieria

y Teemología

\section{Aกัต 11 No 29}

Enero - Abril 2021

Tercera Época

Maracaibo-Venezuela 


\title{
Organizational modeling in production processes of cluster profiles for urban environments
}

\author{
Azariy Abramovich Lapidus* \\ Dmitriy Vladimirovich Topchiy ${ }^{* *}$
}

\begin{abstract}
One of the most important aspects of the development of the urban environment is the comprehensive reconstruction of the municipal development territories, with the aim of creating favorable living conditions and the effective use of the production, engineering, scientific, and other potentials of the complex of edification. The structural condition of many industrial buildings means that they can be operated for more than a decade. This coefficient sparks great interest in industrial buildings precisely for the purpose of their redistribution, rather than reconstruction or demolition combined with new construction. The objective of this study is to define an algorithm for organizational and technological construction, in order to determine the redistribution of industrial facilities. The methodology used refers to the dependency graphs of the relative time loss, versus the redistribution coefficient and also the economic efficiency of the project, versus the actual duration of the construction and installation. From this methodology an adequate mathematical model is introduced.
\end{abstract}

KEYWORDS: production organization, redistribution organization methods, redistribution coefficients, redistribution of industrial territories, the effectiveness of organizational and technological solutions.

*Doctor of Technical Sciences, Professor, Moscow State University of Civil Engineering, Yaroslavskoe highway, 26, 129337, Moscow, Russian Federation, SPINcode: 8192-2653. Author ID:364784, ORCID ID: 0000-0001-7846-5770, info@buildpro.press

**Ph.D. in Technical Science, Associate Professor, Moscow State University of Civil Engineering, Yaroslavskoe highway, 26, 129337, Moscow, Russian Federation, SPIN code: 3956-9376. Author ID: 631269, ORCID ID: 0000-0002-3697-9201

Recibido: 24/01/2020

Aceptado: 28/02/2020 


\section{Modelado organizacional en procesos de producción de perfiles de clusters para entornos urbanos}

RESUMEN

Uno de los aspectos más importantes del desarrollo del entorno urbano es la reconstrucción integral de los territorios del desarrollo municipal, con el objetivo de crear condiciones de vida favorables y el uso efectivo de los potenciales de producción, ingeniería, científicos, y otros del complejo de edificación. La condición estructural de muchos edificios industriales significa que pueden ser operados por más de una década. Este coeficiente provoca un gran interés en los edificios industriales precisamente con el propósito de su redistribución, en lugar de la reconstrucción o demolición combinada con una nueva construcción. El objetivo de este estudio consiste en definir un algoritmo para la construcción organizacional y tecnológica, a fin de determinar la redistribución de instalaciones industriales. La metodología utilizada se refiere a los gráficos de dependencia de la pérdida de tiempo relativa, versus el coeficiente de redistribución y también la eficiencia económica del proyecto, versus la duración real de la construcción y la instalación. A partir de esta metodología se introduce un modelo matemático adecuado.

PALABRAS CLAVE: organización de producción, métodos de organización de redistribución, coeficientes de redistribución, redistribución de territorios industriales, la efectividad de las soluciones organizativas y tecnológicas.

\section{Introduction}

The article deals with the principles of creating a unified system of modules interacting with each other in the implementation of projects for the conversion of industrial facilities. The authors describe the main criteria of forming a complex organizational system, which includes a large number of functional subsystems and modules related to investment, design, production and information components of the project structure. For decades, urban planning of various cities and megacities in the Soviet Union and later in Russia was formed on the same basic principles providing clearly distinguished contours of residential buildings, industrial areas, as well as forest areas and urban infrastructure. Over time, the urban environment absorbed new territories, developing not only geographically, but also forming new modern social requirements. Thus, new principles to design space-planning solutions of residential premises of apartment buildings and requirements for the arrangement of "green" 
urban areas were formed. In addition, the approach to the preservation and development of urban Geoecology has changed significantly. Basically, this factor served as a basis for the formation of municipal programs for renovation of industrial areas that have an impact on the urban environment (Aliakbar et al., 2019; Daeyoung $\&$ Park, 2006; Sugiantiningsih et al., 2019; Zeibote et al., 2019).

By creating qualitative and quantitative characteristics of individual elements of the system under consideration, it is possible to formulate the basic requirements for the source data necessary to create a structured model of organizational design and project management. At the same time, the system should function reliably in the interaction of all integrated structures of the project under the influence of the external environment. The principles and nature of urban clusters are described in detail, their separate types, as well as the relationship and the main criteria for their functioning are highlighted.

\section{Literature review}

Organizational and technological models of re-profiling using expert assessments can be classified as follows:

1) Full redevelopment. This type of redevelopment implies a radical redevelopment of the territory and real estate, starting with the change in the purpose of the land, the approval of a new project and ending with the laying of new engineering networks and the organization of new transport interchanges (Eddelani et al., 2019). Full redevelopment involves a complex of marketing research, development of the project concept and its coordination, as well as elaboration of the architectural idea. Exclusively land is used in this type of redevelopment.

2) Partial redevelopment. This type of redevelopment involves the redevelopment of urban areas and some facilities, with the modernization or renewal of existing transport interchanges and utilities. In this case, it is not always carried out to change the purpose of the land, and the future project is often designed within the existing purpose, in some cases applying small adjustments. As a rule, office warehouse or logistics complexes with administrative buildings are developed in this way. In the case of partial redevelopment, existing land and some existing facilities are 
used, which are usually undergoing reconstruction or modernization.

3) Surface redevelopment. This type of redevelopment, as a rule, does not imply serious, fundamental changes to the existing facilities. Either administrative buildings or separate workshops are subject to such redevelopment. According to this option, as a rule, warehouse complexes are built in cases where a radical change in transport routes, access roads and engineering infrastructure facilities is not required.

To get acquainted with the current state of affairs in the issue under study, as well as to study the latest developments, it is necessary to refer to scientific publications of domestic and foreign format.

According to Abramov who stresses the relevance of the topic adopted for the study, at present, well planned and competently staffed integrated structural construction units will help achieve a high level of reliability and labor productivity and avoid negative (extraordinary) situations during the construction period eventually ensuring improved project performance (Abramov, 2019).

In general redesigning is worthy of attention by the method of reforming the structures and management functions in an enterprise in order to solve the problems of adapting to the conditions of uncertainty and rapid changes in the external environment.

The process of enterprise re-profiling can be represented in three stages:

1) Situational analysis and planning of the program for restructuring measures;

2) Implementation of the enterprise re-profiling program;

3) Monitoring the process of re-profiling and evaluating the effectiveness of ongoing activities.

This study is aimed at improving and facilitating the first stage of the life cycle of industrial re-profiling and planning. The methods and algorithms developed in the paper will allow for more efficient analysis and planning of future events.

As noted by Lapidus and Topchiy, neither at the stage of planning nor at the stage of implementation there are effective, scientifically based systems in Russia (Lapidus \& Topchiy, 2019). The processes on object repurposing that started in the 1990s were chaotic and non-systemic. Development companies did not form structured hierarchical systems of management and control over such projects. 
Besides, there was no system analysis and assessment of a possibility of a form, type and techniques for carrying out similar works. The systematization of management and monitoring in the implementation of re-profiling projects is also not structured and has no scientifically sound deterministic form (Newton, 2016).

In order to solve the mentioned problem, the authors consider the use of an information complex interaction system consisting of a large number of different functional subsystems and modules, including investment, organizationaltechnological and informational ones. In addition, the main elements of this information system should be grouped into four main functional and informational macroblocks, one of which is aimed to develop the design framework, allocate resources, and calculate the project life and costs necessary for the implementation of the project (Sung \& Lee, 2015).

Such parameters as the project cost, number of working shifts a day, number of working days a week, coefficient of combination of works, financing conditions are specified as the most general factors influencing the re-profiling process planning and being interrelated (Zueva et al., 2019). It is advisable to establish relationship between these parameters using the mathematical theory of experiment planning, which is a fundamental part of experimental and statistical modeling theory (Menelyuk \& Lobakova, 2016).

Thus, the literary analysis confirms the relevance of the topic accepted for study and enables to identify the most important factors determining the process of re-profiling at the planning stage and the possibility of finding a relationship between them. The main indicators, based on the scientific sources discussed above, include economic efficiency, intra-shift loss of time, the amount of work in the conversion. Dependencies between them will be established by using the known graphs of the relationship between the values under consideration, or on the basis of the study, if there is no known relationship.

\section{Methodology}

The main study models will be the dependency graphs of values:

1. The relative time loss versus the redeployment coefficient; 
REVISTA DE LA UNIVERSIDAD DEL ZULIA. $3^{a}$ época. Año 11 N² 29, 2020

Lapidus and Topchiy/// Organizational modeling in production processes of cluster... 392-411

2. The project economic efficiency versus the actual construction and installation duration (Zueva et al., 2019)

As a result of the study, we plan to obtain an experimental graph of the project economic effect dependence on the redeployment coefficient.

The time loss is determined by the following formula (1) (Topchiy et al., 2019):

$P=\frac{t_{\text {loss }}}{T_{r r}}$,

where $\mathrm{P}$ is the relative value of time loss; $\mathrm{t}_{\text {loss }}$ is the number of shifts in which it is impossible to carry out construction and installation due to the characteristics of the redeployed facility, given, for instance, its location or duration of an activity during construction; $\mathrm{T}_{\mathrm{cr}}$ is the critical path value (in shifts) determining the construction duration planned, regardless of the working time loss.

The redeployment coefficient is determined by formula (2) (Abramov, 2019):

$$
C_{\text {red }}=\frac{s_{\text {pwa }}}{s} \text {, }
$$

where $C_{\text {red }}$ is the redeployment coefficient; $S_{\text {pwa }}$ is the industrial facility area subject to construction; in other words, the planned work area; $S$ is the total industrial facility area.

Economic efficiency is determined by formula (3):

$$
E=\frac{\mathrm{C}_{\text {est }}}{\mathrm{C}_{\text {act }}}
$$

where $\mathrm{E}$ is the economic project efficiency determined by the degree of decrease in the actual estimated construction cost compared to the project cost; $C_{\text {est }}$ - the estimated cost of construction works; $C_{a c t}-$ the actual cost of construction works.

The actual work duration is determined by formula (4) (Newton, 2016):

$$
\mathrm{T}_{\text {act }}=\frac{t_{\text {loss }}+\mathrm{T}_{c r}}{\mathrm{~T}_{\text {cr }}},
$$

where $T_{\text {act }}$ is the relative actual work duration defined as the ratio of actual duration regarding the time loss to the critical path value.

It must be noted that the project economic efficiency dependence on the actual construction and installation duration is an element of a probabilistic approach to the estimation of organizational and technological construction indicators considered in some scientific literature sources (Jensen et al., 2018).

The most probable duration, compared to the critical path value reflecting the 
REVISTA DE LA UNIVERSIDAD DEL ZULIA. $3^{a}$ época. Año 11 N 29, 2020

Lapidus and Topchiy/// Organizational modeling in production processes of cluster... 392-411

planned duration, is determined by formula (5):

$\mathrm{T}_{m p}=\mathrm{T}_{c r}+3 \sigma$,

where $T_{m p}$ is the most probable construction duration; $\sigma$ is the mean-square error of duration planning.

Based on construction experience and its planning (Joblot et al., 2019), we can assume (6) that:

$$
\sigma=0.05 \mathrm{~T}_{\text {cr }}
$$

With regard to the assumption (6), formula (5) can be transformed into equation (7):

$$
\mathrm{T}_{m p}=\mathrm{T}_{c r}+3 \times 0.05 \mathrm{~T}_{c r}=1.15 \mathrm{~T}_{c r}
$$

With two critical points corresponding to the critical path value and the most probable construction duration, the project economic efficiency dependence on the actual construction and installation duration may be built using the data from Appendix 1.

The result is shown in Figure l.

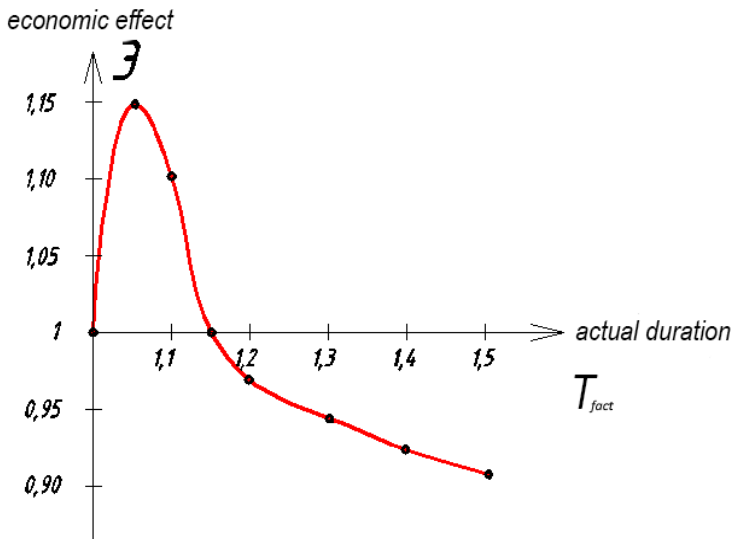

Figure 1 . The project economic efficiency versus the actual work duration

Dependence of the relative time loss on the redeployment coefficient is an unknown value; it is this relationship that will be the main subject of this scientific study. This ratio is known only for its nature, which is an inverse relationship (Figure 2) (Abramov et al., 2016). 


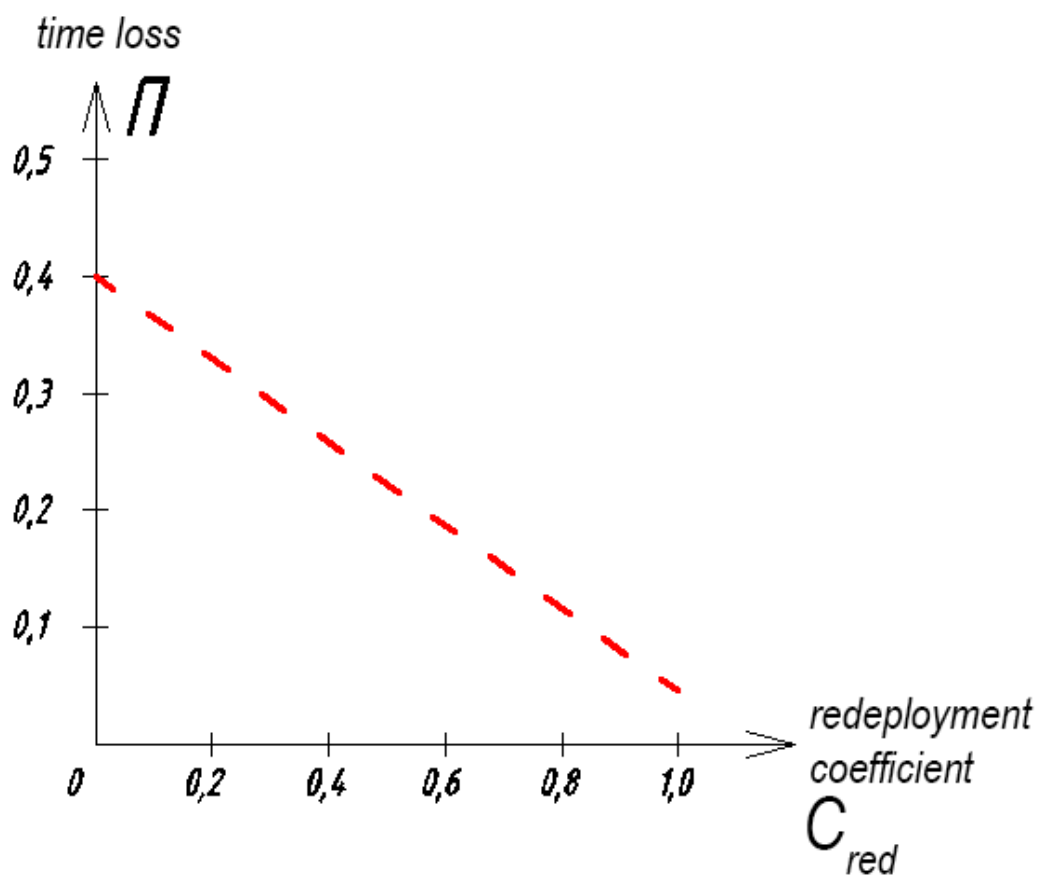

Figure 2. The nature of the relative time loss dependence on the redeployment coefficient.

In what follows a flow chart where can introduce the procedure has been done through this study is schematically depicted (figure 3).

3. Results and discussion

To accurately determine the points on graph 2 and draw up a curve, an expert survey must be conducted. The survey will be performed according to specially prepared questionnaires given in Figure 4. The experts' aim will be to determine the relative time loss during construction at various redeployment coefficient values. The values varying from 0 to $l$ with an interval of 0.2 are shown in the questionnaire in the table to create a statistically representative data array equal to six points. 
REVISTA DE LA UNIVERSIDAD DEL ZULIA. $3^{a}$ época. Año 11 N 29, 2020 Lapidus and Topchiy/// Organizational modeling in production processes of cluster... 392-411

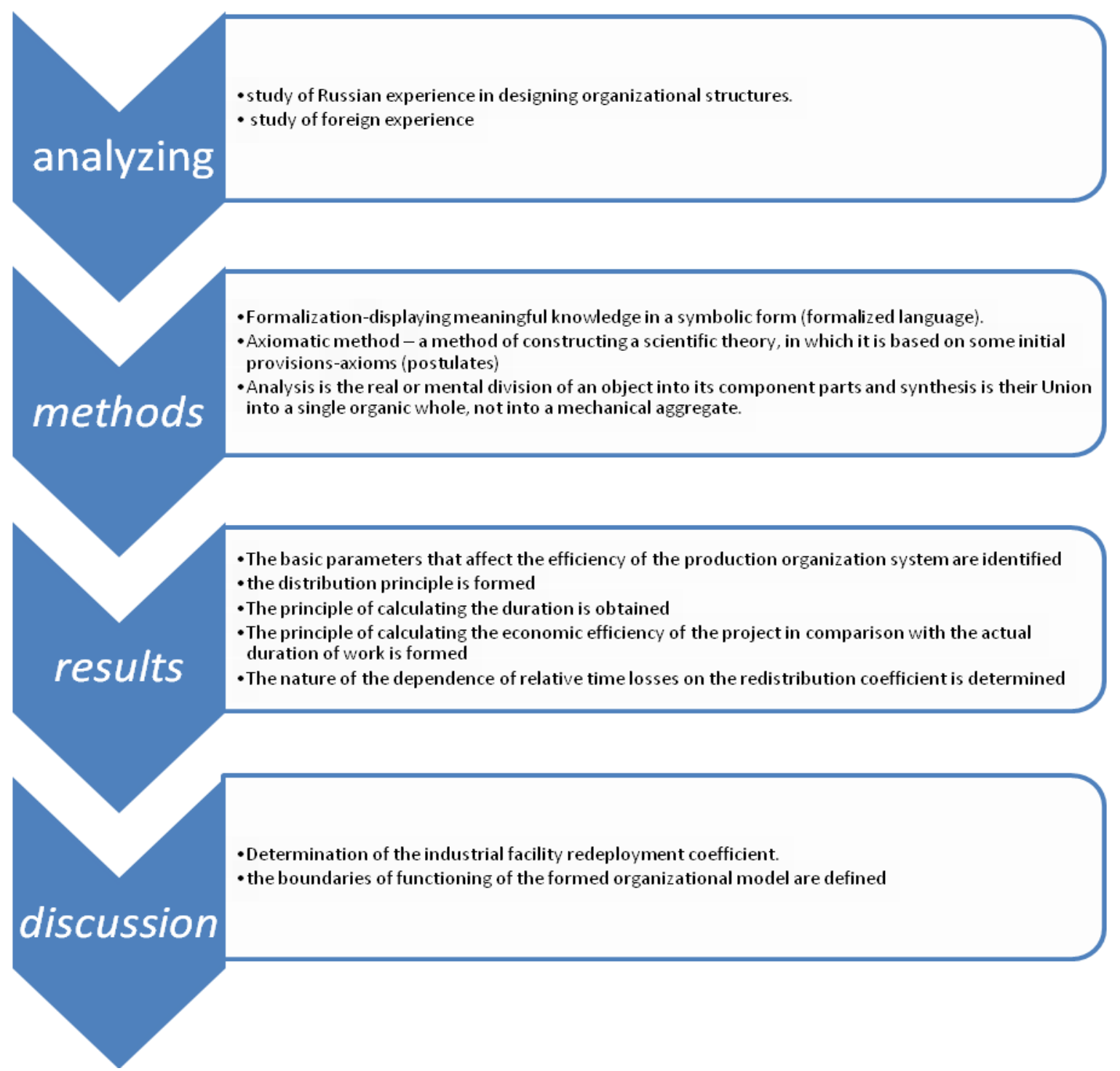

Figure 3. System model

To determine the required number of experts who must participate in the study to create a representative statistical data array, we shall use formula (8) obtained during the generalization of the mathematical data statistical analysis basics (Pukhkal \& Mottaeva, 2018):

$$
m=\frac{h^{2} \cdot r_{a} \cdot r_{o}}{\Delta^{2}}
$$


REVISTA DE LA UNIVERSIDAD DEL ZULIA. $3^{a}$ época. Año 11 N 29, 2020

Lapidus and Topchiy/// Organizational modeling in production processes of cluster... 392-411

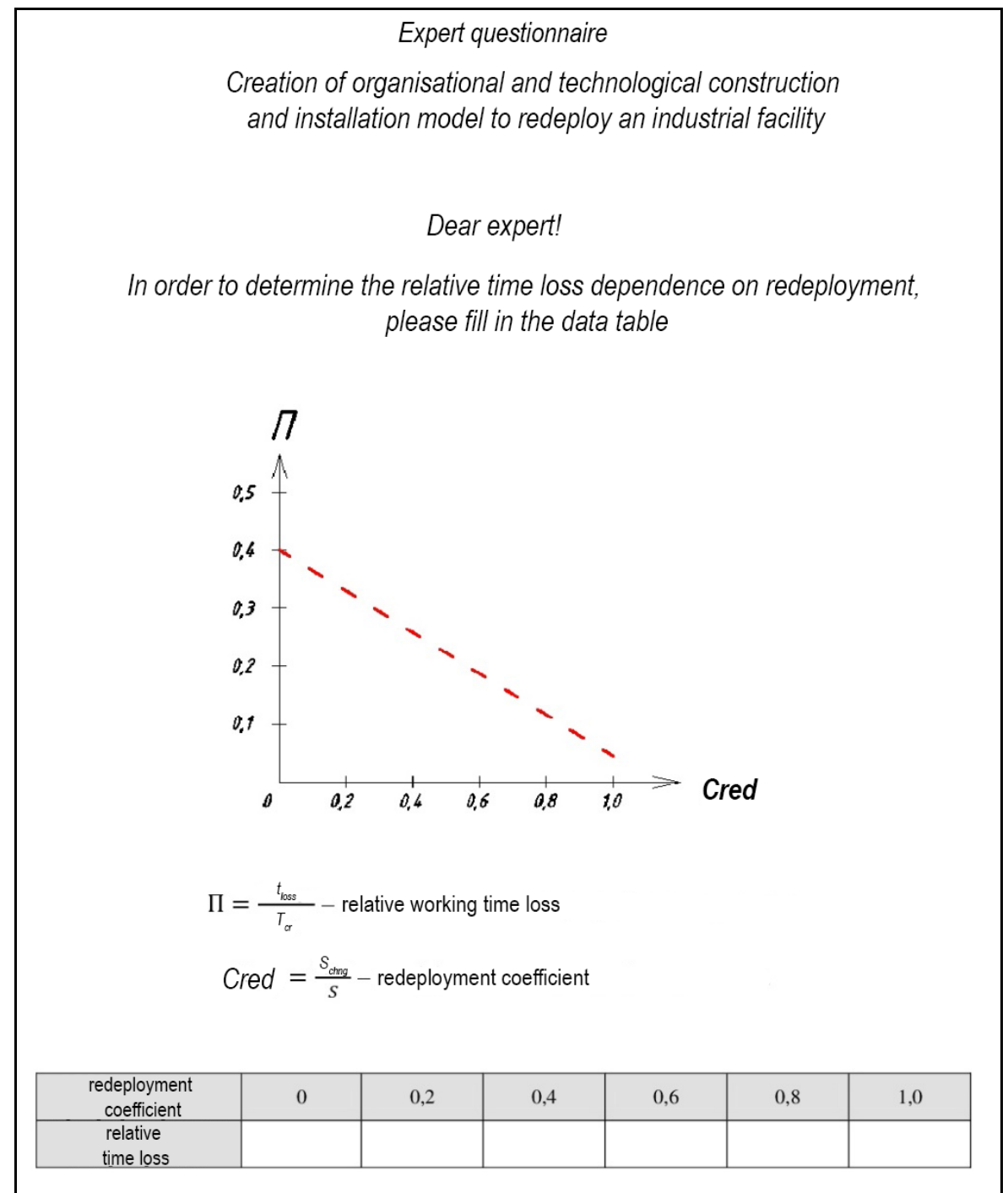

Figure 4. Expert survey questionnaire.

Where $m$ is the required minimum number of experts; $h$ is the confidence coefficient; $r_{a}$ is the proportion of sample elements with this attribute; $r_{o}$ is the proportion of sample elements without this attribute; $\Delta$ is the representativeness error.

The confidence coefficient study is expressed as a percentage indicating an assessment degree of the confidence interval boundaries for the studied values and is usually equal to 80-99\% (Lapidus \& Abramov, 2018).

Taking the confidence coefficient value equal to $90 \%$, we will get:

$$
\begin{aligned}
& h=0.9 ; \\
& r_{a}=h=0.9 ;
\end{aligned}
$$




$$
\begin{aligned}
& r_{o}=1-r_{a}=1-0.9=0.1 ; \\
& \Delta=1-h=1-0.9=0.1 ; \\
& m=\frac{h^{2} \cdot r_{a} \cdot r_{o}}{\Delta^{2}}=\frac{0.9^{2} \cdot 0,9 \cdot 0.1}{0.1^{2}} \approx 8
\end{aligned}
$$

A study with a known representativeness error not exceeding 10\% must be conducted by 8 experts having the necessary competencies in the study subject.

After determining the study methods, models and parameters, as well as the required number of experts, it was possible to obtain statistical data.

The data of questionnaires of the expert survey participants were summarized in Table 1

Table l. Expert survey data.

\begin{tabular}{|c|c|c|c|c|c|c|}
\hline Redeployment coefficient & 0 & 0.2 & $\mathbf{0 . 4}$ & $\mathbf{0 . 6}$ & $\mathbf{0 . 8}$ & $\mathbf{1} .0$ \\
\hline Expert 1 & 0.4 & 0.35 & 0.3 & 0.25 & 0.2 & 0.1 \\
\hline Expert 2 & 0.45 & 0.4 & 0.33 & 0.25 & 0.15 & 0.05 \\
\hline Expert 3 & 0.5 & 0.47 & 0.37 & 0.27 & 0.1 & 0 \\
\hline Expert 4 & 0.44 & 0.45 & 0.4 & 0.22 & 0.1 & 0 \\
\hline Expert 5 & 0.5 & 0.42 & 0.35 & 0.28 & 0.12 & 0.05 \\
\hline Expert 6 & 0.42 & 0.4 & 0.35 & 0.2 & 0.1 & 0.03 \\
\hline Expert 7 & 0.5 & 0.44 & 0.4 & 0.27 & 0.12 & 0.05 \\
\hline Expert 8 & 0.47 & 0.4 & 0.35 & 0.23 & 0.1 & 0.04 \\
\hline
\end{tabular}

After collecting the data, one must proceed to process it mathematically. The Kolmogorov criterion is designed to verify that the analyzed data sample belongs to a certain distribution law. If this criterion meets the verification condition, the statistical hypothesis about the consistency of expert opinions will be confirmed, i.e. the survey results will be considered representative and the data may be subject to further study. 
REVISTA DE LA UNIVERSIDAD DEL ZULIA. $3^{a}$ época. Año 11 N 29, 2020 Lapidus and Topchiy/// Organizational modeling in production processes of cluster... 392-411

Step 1. We shall define cumulative expert survey results (Table 2).

Table 2. Cumulative expert survey results.

\begin{tabular}{|c|c|c|c|c|c|c|c|c|}
\hline No & Expert & Expert & Expert & Expert & Expert & Expert & Expert & Expert \\
$\mathbf{1}$ & $\mathbf{2}$ & $\mathbf{3}$ & $\mathbf{4}$ & $\mathbf{5}$ & 6 & 7 & 8 \\
\hline 1 & 0.40 & 0.45 & 0.50 & 0.44 & 0.50 & 0.42 & 0.50 & 0.47 \\
\hline 2 & 0.75 & 0.85 & 0.97 & 0.89 & 0.92 & 0.82 & 0.94 & 0.87 \\
\hline 3 & 1.05 & 1.18 & 1.34 & 1.29 & 1.27 & 1.17 & 1.34 & 1.22 \\
\hline 4 & 1.30 & 1.43 & 1.61 & 1.51 & 1.55 & 1.37 & 1.61 & 1.45 \\
\hline 5 & 1.50 & 1.58 & 1.71 & 1.61 & 1.67 & 1.47 & 1.73 & 1.55 \\
\hline 6 & 1.60 & 1.63 & 1.71 & 1.61 & 1.72 & 1.50 & 1.78 & 1.59 \\
\hline
\end{tabular}

Step 2. We shall calculate the relatively accumulated frequency differences in the opinions of experts (Table 3).

Table 3. Calculation of parameters for data analysis.

\begin{tabular}{|c|c|c|c|c|c|c|c|c|c|}
\hline No. & fl & f2 & f3 & f4 & f5 & f6 & f7 & f8 & D \\
\hline 1 & 0.250 & 0.281 & 0.313 & 0.275 & 0.313 & 0.263 & 0.313 & 0.294 & 0.063 \\
\hline 2 & 0.469 & 0.531 & 0.606 & 0.556 & 0.575 & 0.513 & 0.588 & 0.544 & 0.138 \\
\hline 3 & 0.656 & 0.738 & 0.838 & 0.806 & 0.794 & 0.731 & 0.838 & 0.763 & 0.181 \\
\hline 4 & 0.813 & 0.894 & 1.006 & 0.944 & 0.969 & 0.856 & 1.006 & 0.906 & 0.194 \\
\hline 5 & 0.938 & 0.988 & 1.069 & 1.006 & 1.044 & 0.919 & 1.081 & 0.969 & 0.163 \\
\hline 6 & 1.000 & 1.019 & 1.069 & 1.006 & 1.075 & 0.938 & 1.113 & 0.994 & 0.175 \\
\hline
\end{tabular}

Table 3 presents the following data:

$f$ is the relatively accumulated frequency (relationship of the current value of $n$ to the maximum);

$D$ is the difference between the maximum and minimum values relative to the accumulated frequencies in each interval.

The accumulated results are calculated by formula (9):

$n_{i}=n_{i}+n_{i-1}$, 
where $n$ is the accumulated expert survey result; $i$ is the interval number.

The relative accumulated frequency is calculated by formula (10):

$$
f_{i}=\frac{n_{i}}{\max \left(n_{i}\right)} \text {, }
$$

where $f$ is the relative accumulated frequency; $i$ is the interval number; $\max (n)$ is the maximum value of the accumulated result.

The difference is calculated by formula (11):

$$
D_{i}=\max (f)-\min (f) \text {, }
$$

where $D$ is the difference relative to the accumulated frequencies; $i$ is the interval number; $\max (f)$ is the maximum value relative to the accumulated frequency in this interval; $\min (f)$ is the minimum value relative to the accumulated frequency in this interval.

Step 3. Subsequently, the maximum value of the difference $D$ is determined compared to the empirical critical difference value $\mathrm{D}_{\text {crit }}$ calculated according to the table of critical difference values in relative frequencies

$D_{\text {crit }}=0.325$,

where $D_{\text {crit }}$ is the critical value of the difference in relative frequencies.

$N=13.14$ is the sample size of the analyzed data defined as the sum of all the expert survey results.

The largest estimated value is equal to $D_{\max }=0.194$ (Pezeshki \& Ivari, 2018).

Since

$D_{\max }<D_{\text {crit }}$,

$0.194<0.325$.

The assumption of the consistency of expert opinions in the survey results is confirmed.

Since, as a result of statistical analysis, the expert survey data given in Table $l$ is recognized as representative, we shall use it as a mathematical basis for determining the previously unknown dependence of relative time losses on the redeployment coefficient. The average expert survey data from Summary Table 1 is given in Table 4 (Hasik et al., 2019). 
Table 4 . The average expert survey values.

\begin{tabular}{|l|l|l|l|l|l|l|}
\hline Redeployment coefficient & 0 & 0.2 & 0.4 & 0.6 & 0.8 & 1.0 \\
\hline Relative time loss & 0.46 & 0.42 & 0.36 & 0.25 & 0.12 & 0.04 \\
\hline
\end{tabular}

A graph of the desired dependence was plotted according to Figure 5.

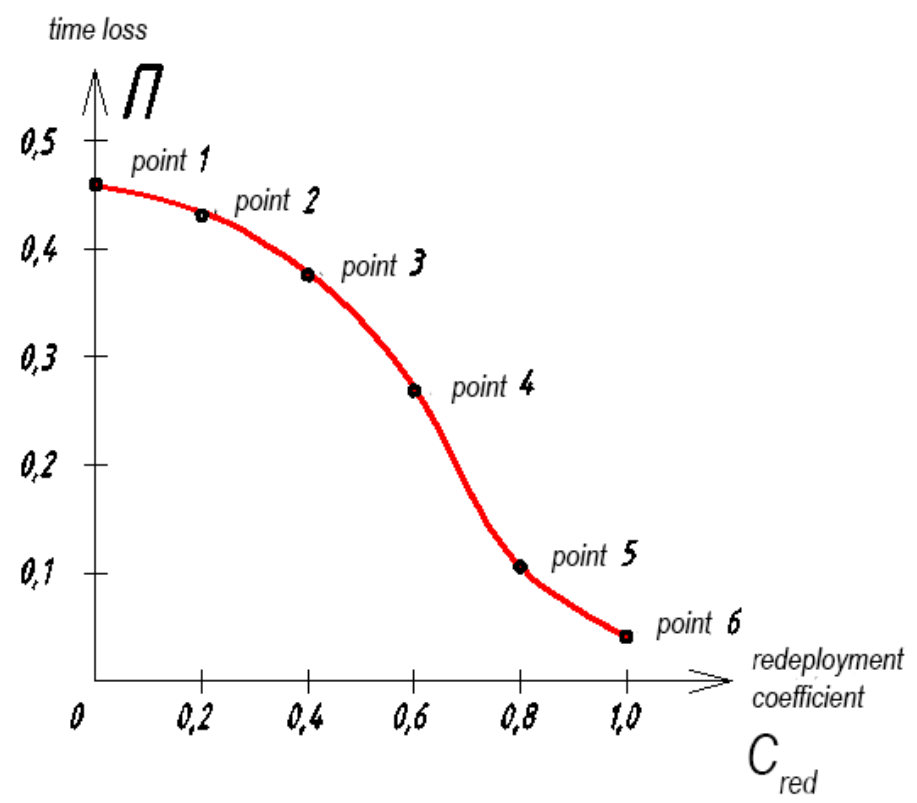

Figure 5. The relative time loss versus the redeployment coefficient.

By summarizing the graphs presented in Figures 1 and 4, the project economic effect relationship with the redeployment coefficient may be determined.

To determine the key point of the graph, we shall use Figure 5. The economic efficiency graph (Figure 1 ) goes over a value of 1 at a point corresponding to a time loss of $0.15 \mathrm{~T}_{\text {cr. }}$. For the redeployment volume, this value will be 0.74 .

Thus, the coefficient value of 0.74 accounting for time losses due to the redeployment process characteristics does not affect the quality and accuracy of the organizational and technological model determining the planned construction and installation duration. 


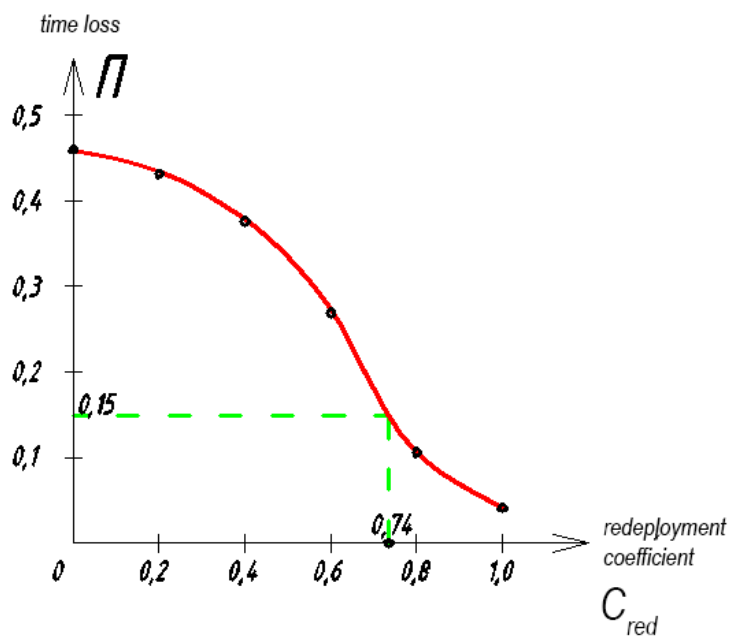

Figure 6. Determining the key value of the redeployment coefficient.

The final graph of the project economic effect dependence on the redeployment coefficient is given in Figure 7.

The values on the graph are obtained in the following way:

According to a dependence of 1 , with construction duration of 1.1, the economic effect is 1.1, which means that, according to a dependence of 4 , for the relative time loss of 0.1, the redeployment coefficient will be 0.85. Further calculations are summarized in Table 5.

Table 5. Determining the economic effect.

\begin{tabular}{|c|c|c|c|c|}
\hline Dependence & \multicolumn{2}{|c|}{ Figure l } & \multicolumn{2}{c|}{ Figure 4 } \\
\hline Indicator & $\mathbf{T}_{\text {act }}$ & $\mathrm{E}$ & $\mathrm{P}$ & $\mathrm{C}_{\text {red }}$ \\
\hline Point 1 & 1.00 & 1.00 & 0.00 & 1.00 \\
\hline Point 2 & 1.10 & 1.10 & 0.10 & 0.85 \\
\hline Point 3 & 1.15 & 1.00 & 0.15 & 0.74 \\
\hline Point 4 & 1.20 & 0.97 & 0.20 & 0.68 \\
\hline Point 5 & 1.30 & 0.93 & 0.30 & 0.55 \\
\hline Point 6 & 1.40 & 0.91 & 0.40 & 0.32 \\
\hline
\end{tabular}




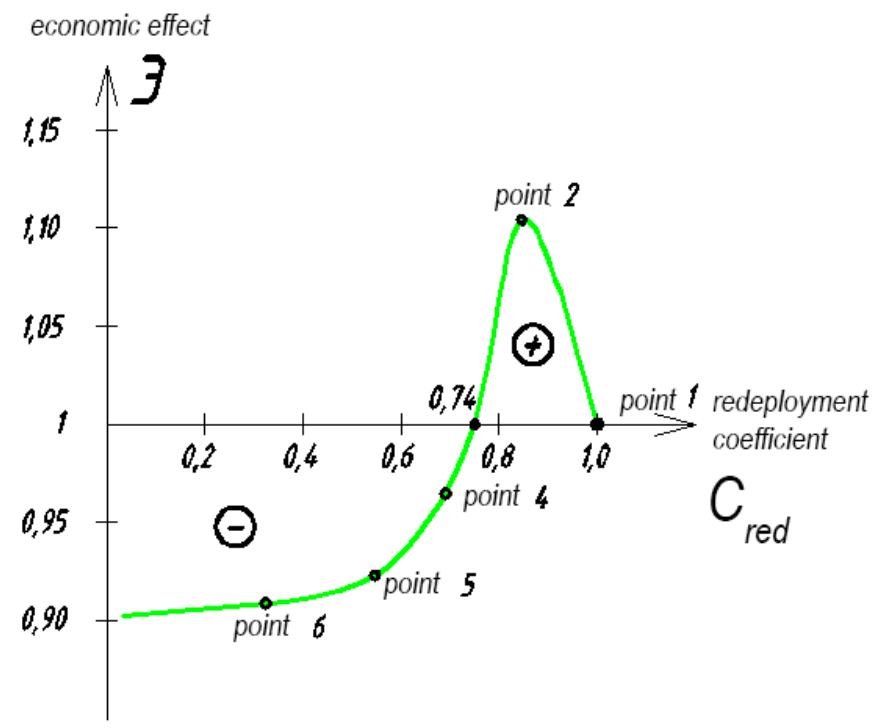

Figure 7. Experimental dependence of the project economic effect on the redeployment coefficient.

According to the dependence graph, with a redeployment coefficient ranging from 0.74 to 1 , the use of standard organizational and technological models does not negatively affect the economic project efficiency due to insignificant losses of working time because of work peculiarities during the redeployment of an industrial facility. Redeployment gives employees whose jobs are at risk the chance to find a new job at the University. Hiring managers can use redeployment to find current employees to fill their jobs.

There are a number of reasons why an employee's job can be at risk, including limited funding and organisational change. If your job is at risk and you have 12 months or more continuous service at the University you can use the Redeployment service. The service has an online register for hiring managers to use and a jobs portal where jobs are advertised to redeployees only.

Redeployment is committed to helping to maintain job security for employees. By hiring a redeployee we can keep the knowledge, skills and experience of an employee who is already loyal to the University.

When the coefficient value ranges from 0 to 0.74 (most facility redeployment cases), standard models have a negative impact on economic efficiency, since they do not consider the specifics of the work. In this case, the redeployment features are 
considered by the planned increase in the work duration determined by the redeployment coefficient dependence on the loss of working time (Figure 4).

As a result of a scientific study conducted using the expert assessment method by means of a questionnaire, including statistical data analysis according to the Kolmogorov criterion, an interconnection between such industrial facility parameters as relative time losses $\rightarrow$ redeployment coefficient, as well as the project economic effect $\rightarrow$ redeployment coefficient was established.

In this paper, we considered the problem of surveillance coverage evaluation undertaken by measuring the dispersion of an redeployment network and that of a redeployment method for maximizing coverage. In the former perspective, this paper describes deployment entropy as a novel quantitative measurement of distribution of redeployment $\mathrm{s}$ when they execute surveillance coverage mission. The properties of deployment entropy make it a reasonable method to measure the distribution. In the later perspective, the two-level redeployment method is developed to relocate the redeployment $s$ to achieve an even distribution. Some simulation results reveal that the proposed algorithm can improve the coverage percentage of the redeployment $s$ network no matter when the redeployment is randomly deployed in the interested region or the redeployment.

The simulation also shows that our proposed two-level redeployment scheme has a lower movement cost when achieving the same coverage percentage as the onelevel scheme.

\section{Conclusions}

According to the study results, the following algorithm for the organizational and technological construction and installation model development may be presented:

1. Determination of the industrial facility redeployment coefficient.

2. If the coefficient ranges from 0.74 to 1 , the organizational and technological model is developed in the same way as for a new construction project.

If the coefficient ranges from 0 to 0.74 , to develop an accurate organizational and technological model, the relative time loss due to the peculiarities of a construction work must be considered. Time loss is determined graphically from the 
REVISTA DE LA UNIVERSIDAD DEL ZULIA. $3^{a}$ época. Año 11 N 29, 2020

Lapidus and Topchiy/// Organizational modeling in production processes of cluster... 392-411

curve given in Figure 4. Regarding the time loss increasing the planned work duration at the construction preparation stage, there is no need to make emergency decisions during a redeployment project if the work duration increases due to unforeseen circumstances. This coefficient is responsible for the increase in the economic effect.

The identified dependencies made it possible to create a tool for evaluating the effectiveness of organizational methods for re-profiling industrial areas. The absence of such methods for designing organizational structures previously did not provide an opportunity to calculate optimal, rational and effective methods of construction and installation work.

\section{Conflicts of Interest}

The authors declare no conflict of interest.

\section{Acknowledgement}

The authors express their gratitude to the staff of the Moscow state university of construction, in particular to the staff of the Department of technology and organization of construction production, as well as to Alexander Menelyuk for detailed systematized information about the basic methods of organizing construction and installation works.

\section{References}

Abramov, I. (2019). Formation of integrated structural units using the systematic and integrated method when implementing high-rise construction projects. HRC 2017 (HIGH-RISE CONSTRUCTION-2017) E3S Web of Conferences, 1-7. E3S Web of Conferences. https://doi.org/10.1051/e3sconf/20183303075

Abramov, I., Poznakhirko, T., \& Sergeev, A. (2016). The analysis of the functionality of modern systems, methods and scheduling tools. MATEC Web Conf 86, 1-5. MATEC. https://doi.org/ 10.1051/matecconf/20168604063.

Aliakbar, K., Schultz, C., \& Kirkegaard, H. (2019). Constraint-based renovation design support through the renovation domain model. Automation in Construction, 102, 45-58. https://doi.org/10.1016/j.autcon.2019.02.012. 
REVISTA DE LA UNIVERSIDAD DEL ZULIA. 3ª época. Año 11 N² 29, 2020 Lapidus and Topchiy/// Organizational modeling in production processes of cluster... 392-411

Daeyoung, K., \& Park, H.-S. (2006). Innovative construction management method: Assessment of lean construction implementation. KSCE Journal of Civil Engineering, 10(6), 381-388. https://doi.org/10.1007/BF02823976.

Eddelani, O., El Idrissi, N. E., \& Monni, S. (2019). Territorialized forms of production in Morocco: provisional assessment for an own model in gestation. Insights into Regional Development, 1(1), 6-18. https://doi.org/10.9770/IRD.2019.1.1(1).

Hasik, V., Escott, E., Bates, R., Carlisle, S., Faircloth, B., \& Bilec, M. (2019). Comparative whole-building life cycle assessment of renovation and new construction. Building and Environment, 161. https://doi.org/10.1016/j.buildenv.2019.106218.

Jensen, P., Maslesa, E., Berg, J., \& Thuesen, C. (2018). 10 questions concerning sustainable building renovation. Building and Environment, 143, 130-137. https://doi.org/10.1016/j.buildenv.2018.06.051.

Joblot, L., Paviot, T., Deneux, D., \& Lamouri, S. (2019). Building Information Maturity Model specific to the renovation sector. Automation in Construction, 101, 140-159. https://doi.org/10.1016/j.autcon.2019.01.019.

Lapidus, A., \& Abramov, I. (2018). Formation of production structural units within a construction company using the systemic integrated method when implementing high-rise development projects. E3S Web of Conferences, 33. E3S Web of Conferences. https://doi.org/10.1051/e3sconf/20183303066.

Lapidus, A., \& Topchiy, D. (2019). Formation of Methods for Assessing the Effectiveness of Industrial Areas' Renovation Projects. Proceedings of the IOP Conference Series: Materials Science and Engineering, 471, 1-6. https://doi.org/10.1088/1757-899X/471/2/022034.

Menelyuk, A., \& Lobakova, L. (2016). Methodology for choosing effective models for the implementation of buildings reprofiling projects. Bulletin of the Kharkov National Technical University. Series: Management Strategy, Portfolio Management, Programs and Projects, 1, 76-81.

Newton, S. (2016). The Being of Construction Management Expertise. Construction Management and Economics, 34, 7-8. https://doi.org/10.1080/01446193.2016.1164328.

Pezeshki, Z., \& Ivari, S. (2018). Applications of BIM: A Brief Review and Future Outline. Archives of Computational Methods in Engineering, 25(2), 273-312. https://doi.org/DOI: 10.1007/s11831-016-9204-1.

Pukhkal, V., \& Mottaeva, A. (2018). FEM modeling of external walls made of autoclaved aerated concrete blocks. Magazine of Civil Engineering, 81(5), 203-212. https://doi.org/10.18720/MCE.81.20. 
REVISTA DE LA UNIVERSIDAD DEL ZULIA. $3^{a}$ época. Año 11 N 29, 2020 Lapidus and Topchiy/// Organizational modeling in production processes of cluster... 392-411

Sugiantiningsih, A. A. P., Weni, I. M., Hariyanto, T., Tutuko, P., \& Sedyowati, L. (2019). Enhancing Environmental Quality through Community Participation based on Traditional Rules: Empowering the New Role of Pecalang in Bali. Journal of Southwest Jiaotong University, 54(5). https://doi.org/10.35741/issn.0258-2724.54.5.16.

Sung, C., \& Lee, D. (2015). A case study of time/cost analysis for aged-housing renovation using a pre-made BIM database structure. KSCE Journal of Civil Engineering, 19(4), 841-852. https://doi.org/10.1007/sl2205-013-0617-1.

Topchiy, D., Yurgaitis, A., Kravchuk, A., \& Shevchuk, D. (2019). Controlling methods of buildings' energy performance characteristics. Problems of Architecture, Civil Engineering and Environmental Economics (TPACEE 2018) electronic edition. TPACEE 2018. https://doi.org/10.1051/e3sconf/20199102026.

Zeibote, Z., Volkova, T., \& Todorov, K. (2019). The impact of globalization on regional development and competitiveness: cases of selected regions. Insights into Regional Development, 1(1), 33-47. https://doi.org/10.9770/ird.2019.1.1(3).

Zueva, D., Babushkin, E., Topchiy, D., \& Yurgaitis, A. (2019). Construction supervision during capital construction, reconstruction and re-profiling. MATEC Web of Conferences, 1-8. MATEC. https://doi.org/10.1051/matecconf/201926507022. 